\title{
THE PHILOSOPHICAL BACKGROUND OF THE ATHANASIAN DOCTRINE OF SALVATION*
}

The purpose of this presentation is to examine how a fourth-century Alexandrian without formal training in philosophy, a leading figure in the Christian church of his time, was part of the intellectual world in which contemporary Neoplatonists were living. Elected bishop in 328, Athanasius remained in office until 373. During his agitated tenure he was driven five time into exile by his opponents, and these enforced periods of leisure gave him the possibility to write much more than just circumstantial letters and short pamphlets. $\mathrm{He}$ completed an apologetic work in Trier during his first exile from 335 to 337, the double treatise Against the Heathen and On the Incarnation of the Word. When chased from his see in 339 , for six years becoming a political refugee in the Western part of the Empire, he took with him the first draft of a major polemical work which he later edited in the form of three Orations against the Arians. Finally, when he returned once more from a voluntary exile - his third ordeal of that sort - in 362, he brought back to Alexandria his most popular written work, the Life of Antony, the first best-seller of Christian Antiquity after the Christian Bible ${ }^{1}$.

In these writings Athanasius communicates an intellectual legacy deeply marked by the kind of Christian Platonism characteristic of the Alexandrian Church tradition. Since Philo, the Jewish commentator of Torah in the first century CE, and Pantenos or Clement, the first two Christian teachers in the late second and early third century, a remarkable symbiosis had bound together the philosophical culture of the metropolis near the Nile and the Judeo-Christian minority-tradition in Egypt. Older Jewish scholarship had produced the Greek translation of the Hebrew Bible called the Septuagint. Mi-

An oral communication at the Neoplatonic Conference, Catholic University of Lublin 2003, this essay, reworked in its written form, returns to Lublin on Prof. Stanley Longosz's invitation as a gift for Prof. Marek Starowieyski, a highly esteemed colleague.

${ }^{1}$ For a general survey of Athanasius' career, the most comprehensive study is currently Annik Martin's monumental work: Athanasius d'Alexandria et l'Église d'Egypte de $I V^{e}$ siècle (328-373), Rome 1996. 
grant intellectuals, visiting the newly-formed community of Christian believers, had found in Alexandria enough incentives for settling down and opening schools of their own. In that urban milieu, saturated with Gnostic and esoteric trends, and in which enough institutions of higher education flourished for making it the intellectual capital of the Mediterranean world, Plotinus himself completed his whole education. In 233, at the age of twenty-eight, Plotinus enrolled among the students of Ammonios, the most innovative teacher of philosophy in Alexandria at that time, when his ten years older Christian contemporary, Origen, was already a renowned teacher in the Christian didascalion, ready to compose his major metaphysical essay On First Principles. In the early fourth century Athanasius would benefit from the intellectual heritage of the third century, when becoming a student himself under the guidance of the local bishop. At the age of twenty, around 318, he was ordained a deacon, well noticed by the aging bishop Alexander, who engaged him as his secretary for the trip and the assistance to the Council of Nicaea convoked by Emperor Constantine in May of 325. Finally, Alexander designated him as his successor despite the fact that he had not yet reached the required age of thirty. With that irregularity, added to the poisoned atmosphere due to the controversy around the Alexandrian priest Arius and the difficult situation created by the inner division of the Egyptian church since the last persecution over a decade ago, the episcopal ministry of Athanasius, from the $8^{\text {th }}$ of June 328 on, was doomed to challenge him more than his due.

In matters of doctrine the most immediate challenge imposed on the bishop came from the Arian side, which means from disciples of Arius himself, and even more massively from their supporters, a coalition of bishops who disagreed with the decisions of Nicaea 325. By opposing the Nicene formula of faith, they automatically became, in Athanasius' eye, supporters of Arius, condemned by the same synod. The central issue at stake was the essential unity of God understood as Trinity. Before Origen, and even after him, the traditional representation of deity in Alexandrian Christianity (as well as in other churches) was of a ,monarchian" type, a form of Jewish monotheism in a Christian guise, the Father being the ,sole principle" of deity, in which were included the Son and the Holy Spirit. Origen's groundbreaking initiative in $\mathrm{On}$ First Principles ${ }^{2}$ established the clear necessity of introducing philosophical notions into the theory of godhead, such as the notion of an ovoía, an „es-

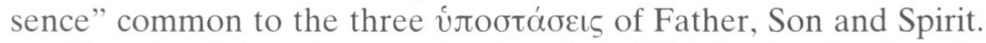

Thereby Origen became the founder of Trinitarian theology in a typically Alexandrian style, blending Platonizing metaphysics with arguments directly taken from Scripture. The revelatory authority of the sacred texts dispensed him in a large measure from the introspective exploration of the human soul,

${ }^{2}$ Cfr. De principiis I 1,7 . 
thanks to which philosophers tempted to reach out into the realm of divine transcendency. The titles given in scripture to each hypostasis and the anthropomorphic narrative of their respective involvement in the history of humankind, as presented in both Testaments, helped the biblical exegete Origen to illustrate in the popular idiom of his believing community the fundamental views of the metaphysician Origen. The Origenian legacy entrusted future generations of theologians with a conceptual construct more exposed to misunderstandings and to rejection than were the candid apologetics of an earlier time. All theological schools struggling against each other after Nicaea, could, in one way or another, pay a common tribute to that same legacy of Origen. Among many other theologians of his time, but more explicitly than all the others, Athanasius of Alexandria invoked the patronage of Origen for his doctrine of God and salvation.

\section{AN ONTOLOGY OF SALVATION}

The main difference between Origen in the third century of Christian thought and Athanasius in the forth is that the forth century bishop found himself much more prepared than his predecessor to investigate the key-notions defining the inner life of divine Trinity. In other words, Athanasius deliberately elaborated on the intimate relationship between the three hypostases, whose separate existence had already been asserted by the third century pioneer. Another basic difference between them is that the Origenian theory of godhead rested on epistemological presuppositions: the way of knowing always indicated for Origen the nature of what is known, and the restored possibility of supernatural knowledge meant for him a successful salvation of humankind, whereas in Athanasius' thought representations of God, cosmos and human destiny, are primarily based on an ontological basis.

At the beginning of its first chapter the earliest essay of Athanasius, entitled Against the Heathen, states:

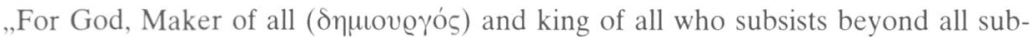
stance and all human thought, as he is good and exceeding beautiful, made through his own Logos, our Savior Jesus Christ, the human race according to his image" ${ }^{3}$.

All notions in that liminal statement are thoroughly Christianized: „God”, the biblical Creator, means in the terms of Plato's Republic, the supreme Being that „subsisted beyond all substance" , a concept and quotation well know in the Christian tradition, already quoted by Justin of Rome in the middle of the

${ }^{3}$ Contra gentes 2, edited and translated R.W. Thomson, Oxford 1971; cfr. PG 25, 5B.

${ }^{4}$ Cfr. Plato, Respublica VI 509b. 
second century ${ }^{5}$ and by Irenaeus of Lyon and Clement of Alexandria near the end of the second and in the early third century, before Plotinus commented on it in Enneads ${ }^{6}$.

The essential property of God's all-transcendent Being is „goodness”, as emphasized in the second apologetic essay of Athanasius, joined with Against the Heathen, the treatise On the Incarnation of the Word, where the liminal statement of Against the Heathen is reiterated: „God is good, rather, he is essentially the source of goodness." Again Athanasius obviously speaks of the biblical creator of the universe, but again his ontological intuition about deity is formulated in the language of a Platonic culture. Further in the same essay On the Incarnation, he explicitly attributes to the essential ,goodness" of God, which he then specifies as God's philanthropy ${ }^{7}$, the salvation of humankind as narrated in the Bible ${ }^{8}$. He insists on the equal „goodness" of the Father and Son in his triadic notion of deity, and he ends by expanding a notion of salvation in which the very being of humankind is rescued from death and corruption. Not only is human self-understanding illumined by the saving Logos, nor is only human behavior transformed, but the very essence of humanity participates in the essence of the Logos who is the Image of God, and who by an iconic participation generates in human nature itself a principle of divinization for human beings. Thus the Athanasian vision of salvation is ontological and therefore the bishop claims that salvation is universal in its essential presuppositions. He deploys the saving intervention of the Logos as a new creation of humankind, as a radical renovation of the human condition, due to the essential ,goodness” of deity.

After many attempts of the critics to catch the original dynamic of philosophical notions in Athanasius' thought which was entirely rooted in the biblical ground, suffice it to note that the fourth century bishop articulates doctrinal statements in his cultural mother tongue impregnated with platonic traditions.

In a later writing Athanasius, at least once, betrays a direct knowledge of Plotinus, when he alludes to the emanation of the supreme Noṽ s,from the Good", and to the emanation of the cosmic „Soul" from the Nov $\varsigma^{9}$. He more often joins Middle Platonic authors, like Albinus, or Christian predecessors like Origen and Eusebius of Caesarea, themselves embedded in Middle Platonism, when he discusses the essential eternity of godhead or the created nature of time, and again when he concludes that „goodness" does not depend on a decision of God's will, but, as Albinus repeated by Origen had stated, by the fact that "Goodness is an essential property of God".

\footnotetext{
${ }^{5}$ Cfr. Justinus, Dialogus cum Judaeo Tryphone 4, 1.

Cfr. Plotinus, Enneades V 5, 6.

Cfr. De incarnatione Verbi 12, 5, PG 25, 117B15.

Cfr. ibidem 43, 4, PG 25, $172 \mathrm{C} 10$.

Cfr. De decretis Nicaenae Synodi 28, PG 25, 468B.
} 
I already observed that the Athanasian idea of salvation, as exposed in the treatise On the Incarnation of the Word, is determined by the author's ontological perception of divine ,goodness”, but turning now from God to humankind as focus, I should not miss the description of the first human beings, which opens each of the two apologetic treatises Against the Heathen and On the Incarnation of the Word. The carefully crafted vignette of Adam and Eve as a frontispiece for his apologetic work is, in my view, highly significant of Athanasius' doctrinal ambition as a newcomer on the intellectual scene of the Alexandrian Church. First I shall quote the passage in Contra gentes of which I have already quoted the first line:

„For God, Maker of all and King of all, who subsists beyond all substance and all human thought, as $\mathrm{He}$ is good and exceeding beautiful, made, through his own Logos, our Savior Jesus Christ, the human race according to his own image. By their resemblance to the Logos he enabled them to contemplate and to know realities, in giving them an idea and a knowledge of their own eternity, so that, by keeping their integrity, they never disregard the notion of God, neither give up to live in communion with the holy ones, but keeping the grace donated by God and keeping also the proper power from the Logos of the Father, they might rejoice in the intimacy of the deity, living a life free from any concern, truly blessed and immortal" 10 .

That original ecstasy of the protoparents inspires an even more precise picture:

„Having nothing that impedes the knowledge of the deity, the human being, thanks to its purity, contemplates forever the Father's Image, the God-Logos after whose Image it was made. It is awestruck when considering the Providence which through the Logos extends to the universe. Being raised above sensible realities and every bodily appearance, the human being through the power of the mind joins the divine and thought-perceived realities in the heavens. Having nothing more to do with bodies and free from the external mixture of their passions, being entirely above itself as it was created from the beginning it then raised up on high beyond the realities of the senses and all things human, and seeing the Logos it also sees in Him the Father of the Logos; it rejoices over what it contemplates and is renewed by its desire towards the Logos" 11 .

\section{THE TRIADIC UNITY OF GODHEAD}

The charming evocation of Genesis 2 in Contra gentes shows how in fourth century Alexandria Christian faith interpreted the mythical story of Adam and Eve at once as real history and as a symbol of universal significance. The spiritual journey of the human mind beyond earthly contingencies is seen as

${ }^{10}$ Contra gentes 2, PG 25, 5D.

11 Ibidem, PG 25, 8A. 
experienced by real people. However, focusing here on the Athanasian ontology of salvation, it is important to observe that nowhere else in his written legacy does Athanasius recall on that original beatitude of Adam and Eve. In the treatise On the Incarnation of the Logos itself, the ,vignette" of the protoparents, as I called it, does not introduce any themes developed subsequently. It rather serves as an antithesis stated in Origenian terms in a stark contrast with the view of salvation emphasized by Athanasius himself. It is true, according to capitula 11 to 16 of De incarnatione, human salvation means a restoration of the original Logos-likeness in the human mind, that innate $x \alpha \tau^{\prime}$ Eixóv $\alpha$ originally imprinted in the voṽ by the Logos-Eixúv, and now again secured for believers by the saviour. But precisely, that section 11-16, which completes capitulum 2 with the vignette of Adam and Eve, Athanasius carefully frames it, first by the section of capitula 8-10 in which he stresses the apostle Paul's dialectic of life and death, and secondly by the capitula 17-32, actually the bulk of the treatise, in which his apologetic demonstration centers on the gospel story of the death and resurrection of Jesus.

Thus the thesis of a salvation eventually made possible through the contemplative power of the mind, as implied by the introductory and Origenian styled vignette of Adam and Eve, is literally squeezed between two sections properly Athanasian, in which the extreme realities of human life and death are directly the concern of God's essential ,goodness" in the saving Logos himself.

In that view proper to Athanasius salvation means no more the recuperation of any original ecstasy by saved human minds as it was implied in Origen's theory. That Athanasian view also excludes a possible vision of the saving Logos contemplated in himself as was the case for Adam and Eve. For Athanasius completely ignored Origen's noetic purity of human beings alienating themselves from their bodily condition trough voluntary asceticism. As the whole essay On the Incarnation of the Logos shows, the Alexandrian bishop promoted an appropriation of divine ,goodness" thanks to the saving efficiency of the incarnate Logos which always keeps believers in their present situation, a situation where faith replaces vision.

If there was something like a Copernican shift achieved by Athanasius inside the Origenian school of thought, I would suggest that in the realm of Alexandrian Christianized Platonism such a shift, best characterized by a concentration on the saving Logos, was to apprehend the ,goodness" of deity in the actual experience of human beings, bound as they are to body and history, rather than by an idealistic focus on any noetic capacity of the human intellect perceiving divine ,goodness" in itself. By operating such a shift Athanasius de facto became the initiator of what may be called an ,incarnational" theology, a Christian theory of godhead with the notion of divine incarnation at its center. Thereby his theological perspective became anthropocentric as had been - for very different reasons - Plotinus' speculation on the Divine. Indeed 
Athanasius' analysis of the spiritual journey uses to describe the interaction between the incarnate Logos and the enlightened mind of believers, whereas Plotinus scrutinized the inner vitality of the mind contemplated in its proper dynamic on such a journey. Keeping true to a Platonic perception of divine "goodness", Athanasius gave it a personified identity in biblical terms and applied it to the figure of an incarnate Logos.

Actually, in his apologetic work Against the Heathen and On the Incarnation of the Logos dating from the first decade of his episcopacy (328-339), Athanasius, like in a first round, positioned himself for the decisive fight of his life $\mathrm{e}^{12}$, which was to face Arianism by composing his famous Orations Against the Arians. In the second part of this presentation I shall briefly comment on the triadic unity of godhead as exposed in the three Contra Arianos.

The apologetic treatise Against the Heathen ends in a litanic celebration of proper attributes of the divine Logos. I quote a few lines in capitula 45 and 46 :

„Knowing the Logos of God people necessarily know as well God, Father of the

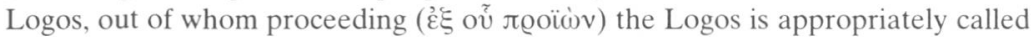

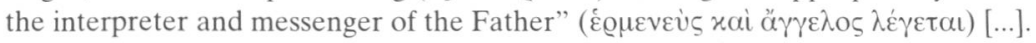
In any case he (the Logos) himself is proper Wisdom (avitoøoфia), proper Word

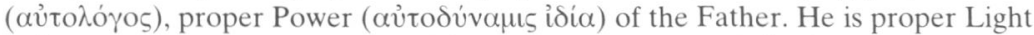

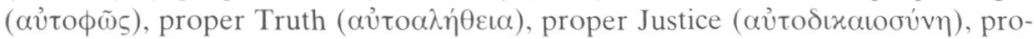

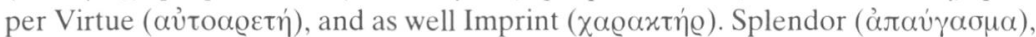
Image (Eixúv) $)^{\prime 13}$.

In all these attribution the prefix $\alpha$ vito is ambivalent: it means for Athanasius at once ,proper to" the Logos and „proper to" the Father. For in conformity with Christian tradition from the New Testament on the concept of the Logos is for Athanasius integrally part of his triadic notion of deity. When starting to compose the first of his three Orations against the Arians shortly after the final editing of Against the Heathen, which means soon after returning from Trier to Alexandria in $337^{14}$, the bishop faced publicly the doctrine of Arius, a doctrine which denied the full eternity and divinity of the Logos. Arius was a generation older than Athanasius, with a mind-set still shaped by the intellectual atmosphere prevalent in third century Alexandria. At that time Arius could as well have met Plotinus before Plotinus left from Rome. Later, in his mature age, - Arius was about sixty years old at the time of the council of Nicaea - he continued thinking in the old-fashioned categories of the monarchian form of ecclesiastical monotheism against which Origen had built up his triadic notion of deity. Arius

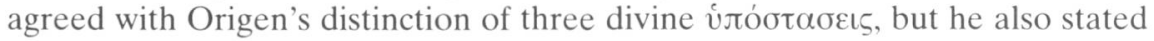

12 Cfr. Ch. Kannengiesser, La date de l'apologie d'Athanase. Contre les Païens et Sur l'incarnation de Verbe, RSR 58 (1970) 383-428; Le Verbe de Dieu selon Athanase d'Alexandrie, Paris 1999.

13 Contra gentes 45-46, PG 25, 89A and 93C.

${ }^{14} \mathrm{Ch}$. Kannengiesser, Athanase d'Alexandrie évêque et écrivain. Une lecture des traités Contre les Ariens, ThH 70, Paris 1983, 374-403. 
their inner and essential hierarchy as required by monarchianism. Verbally close to Origen, he nonetheless contradicted him by stating that the Logos was not of the same substance as the Father: being issued from the Father, the Logos had a beginning, he necessarily belonged to the order of creation, though divine by status and by his transcendent function in the cosmos.

This first conflict of ideas concerning the triadic unity of godhead, based as it was on Origenian principles, created a turmoil not only in Alexandria, but in the whole ecclesiastical administration of the Constantinian empire. Against his will the new Alexandrian bishop, who took over in 328 , three years after Nicaea, found himself pushed to the forefront of the ideological battle lines, and his political involvement in the so-called Arian crisis was to become problematic for historians up to the present day. I shall try to retrace some ideas proper to Athanasius concerning the plural unity of godhead on the supreme level of reality without searching so much for Plotinian elements in the Athanasian doctrine, as others have successfully attempted for instance in the case of Gregory of Nyssa who lived a generation after Athanasius. More modestly, my purpose would limit itself to retracing the Athanasian theory of deity as contemporary of, but hardly connected with, Neoplatonic trends in the intellectual arena of early fourth century Alexandria.

1. A Nicene notion of Deity. The Athanasian notion of deity is thoroughly permeated by the debate around the dogmatic decisions of the Council of Nicaea in May-June 325. In Nicaea an adequate response to the challenge imposed by the Arian objection against the full divinity of the Logos required a new philosophical foundation for the traditional affirmation of God. The inner unity of divine Trinity needed to be reassessed. Since Origen, deity was affirmed in the Alexandrian church as one single substance called either

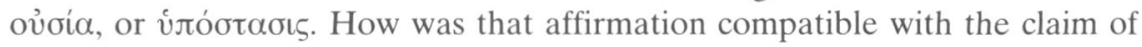
the gospel stories calling Jesus the „Son of God”? In the liturgical practice and in the exercise of preaching, the claim could easily be repeated with all its metaphorical value, but what about its conceptual translation into a formalized discourse of a philosophical kind like the one held by Arius and his

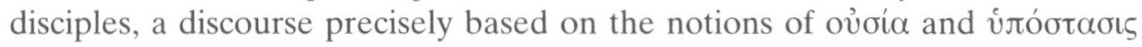
as first introduced into Christian teaching by Origen?

We do not know if and in how an active part the young deacon Athanasius become involved in the Nicene deliberation. One day, in front of two thousand parishioners gathered in the cathedral of Cairo, I was firmly admonished by Pope Shenuda III, the current head of Coptic Christianity, not to underestimate the leading role played by Athanasius at the Council of Nicaea in 325 . The fact is that we know strictly nothing concerning such a leadership, except that long after Athanasius it became in the Coptic tradition part of the devotional saga about this everlasting icon. 
What we know for sure is that in his earliest writings after 328 Athanasius gave voice to his personal perception of the Nicene dogma. First in the enthusiastic terms of the Festal Letters, which were circular letters addressed once a year before Lent and Easter to the whole Egyptian Church, then in the two apologetic treatises of which I have spoken earlier. Mainly in the three Orations against the Arians, the new Alexandrian bishop clearly stated what deity expressly meant for him. Here is what he said:

„God is One and Only and First, but this is not said to the denial of the Son, perish the thought; for he is in that One, and First and Only, as being of that One and Only and First the only Word and Wisdom and Radiance. And He too is the First, as the fullness of the Godhead of the First and Only, being whole and full God"15.

Further on in the same first section of the third Oration Against the Arians Athanasius insists even more on how he understood the ómoov́ros formula of the Nicene Creed:

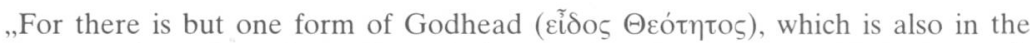
Logos; and one God, the Father, existing by Himself according as $\mathrm{He}$ is above all, and appearing in the Son according as He pervades all things, and in the Spirit according as in Him He acts in all things through the Logos. For thus we confess God to be one through the Triad"16.

In other words Athanasius used the biblical titles of divine Trinity. He established himself as a believer in an objective partnership with a godhead at once transcendent and present in this world. The Bible gave him the proper names of „Father”, „Son”, and „Spirit” for addressing the plural reality of the unique divine substance as he perceived it. His problem was not to demonstrate the existence of that substance, a truth anyway out of question in the Christian community of thought in which he was living, nor was his problem to clarify the link between that divine substance and the universe - which would have been a priority for Plotinus, had he conceived the notion of a personalized godhead; Athanasius' problem was to focus (without much conceptual elaboration) on the essential features of deity questioned by Arius.

Thus he started by engaging into a lengthy argument about divine eternity in order to demonstrate that if a proper ,Son of God" should ever be thought out, that „Son” could only make sense by being equally eternal as the Father. It was the initial demonstration of his first Discourse against the Arians. Another argument, very close, was to assert that the biblical belief in a divine generation inside godhead was acceptable at the sole condition of excluding any change in the perfect and eternally immutable substance of God. In addition to manuy

15 Oratio contra Arianos III 6, PG 26, 333.

16 Ibidem III 15, PG 26, 353B. 
biblical statements used as proofs for such an affirmation Athanasius exploited well-known comparisons like those of the light and its radiance or of the source and the river running out of it. He purified the notion of that divine generation from any anthropomorphic representations, keeping only the idea of a communicative fullness of life by which deity remains identical and one in the dual identity of „Father” and „Son”.

These arguments with extended scriptural proofs led Athanasius, discussing Arian objections, to concentrate on the central concern of his own theological inventiveness. As much as his adversaries he needed a clarification of what the council of Nicaea had declared the „consubstantial” nature of Father and Son. The second Oration against the Arians and a large part of the third present his conclusion.

Despite the fact that divine revelation transmitted by scripture imposes a very distinct image of each hypostatis, or more accurately a very different representation of Father and Son, the rational imperative of their unity prevails. Otherwise, as Athanasius insists one deals with polytheism, and the notion of the Triad becomes unthinkable. In godhead's absolute transcendence no paradoxical alternative is required between the One and the plural, the Giver and the receiving, the Ungenerate and the generated. Athanasius pushes the tension of apparent contradictions in literal predicaments of Scripture to the extreme, only to produce an ever richer and more articulate definition of the relationship between Father and Son in the unique substance of deity. His exuberant orchestration of scriptural references never weakens the clear firmness of his intellectual grasp on the Nicene ómoov́oıv.

2. A post-Nicene doctrine of salvation. The intense concentration of the Alexandrian bishop on the very substance of the Triad, with the main proposes of demonstrating the ónoovoí of the Father and Son, was primarily motivated by its soteriological relevance. Only a Logos proven genuinely divine and of the same substance as the Father could be real saviour. Only a substantial sharing of himself secured by such a Logos could overcome death and save human beings from their internal perversion. In all forms of religious belief, if there is a soteriology at stake, the kind of salvation expected depends on the very notion of deity developed by believers in the different traditions. In the case of Athanasius a powerful biblical background, with the gospel-message as a key for interpreting it, prepared the stage on which he projected his own doctrine of salvation. That doctrine has been well characterized as a doctrine of „divinization”, and its best expression, endlessly repeated by the critics, was found in the words of $D e$ incarnatione: „He was made man that we might be made God”.

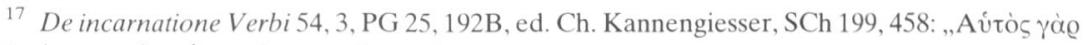

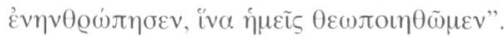


These words summarize in one sentence the whole gospel story, but they also formulate what is proper to the Athanasisn notion of salvation, namely that the divine Logos is identified as salvific only because of his consubstantiality with his Father. Only because in a complete unity with the paternal substance in the Triad could the Logos manifest and effectuate the transcendent presence of God's intimate mystery in the human realm. The communicative nature of Godhead as divine hypostasis, perceived inside the Triad as the source of the distinction and unity of Father and Son, produces in the world where humanity needs to be saved a life-giving effect. The human mind is opened to a renewed perception of the divine presence. As valuated by human beings, human life takes on the full dynamic of the inner vitality of the Triad as revealed by the Logos, and by the Spirit made affordable as a gift for the common believer.

Perfect Eixóv of the Father, the Logos achieves the Logos-like, the $x \alpha \tau$ ' Eixóva, transformation of human beings through a hermeneutical conversion which links them with the very mystery of the consubstantial Triad. A long section of Contra Arianos, in III Oration $^{18}$, develops the notion of that divinizing innovation of human existence by which faith in the incarnate Logos signifies the ontological newness of believers. Hence the union with supreme transcendence, end-stage of any mystical journey, is located here in the earthbound experience of religious faith. A divine transfiguration of all values and all aspects of existence is no more unthinkable in the spatio-temporal conditioning of human existence, because the saving Logos, radically transcendent in his consubstantiality with the Father can in no way be declared affected by the anthropomorphic limits of space and time.

Such a doctrine of divinization or deification permeates the thoughts of Athanasius in all directions. It explains the original aspects of his anthropology inherited from Origen, with its proper notion of the lost and redeemed intellect, the human voṽs, at the core of saving Logos-likeness, also with its rejection of any kind of preexistence of the soul. The doctrine of divinization marks the whole moral teaching of the bishop, with less emphasis on volontarist asceticism in the style of the Origenian discipleship flourishing during Athanasius' life-time in the desertic areas of Egypt, but with a prevalent call on the many challenges of the Christian faith experience, challenges in the daily routine of ordinary life as wonderfully suggested in the so-called Letter to Marcellinus; or challenges in social and political confrontations like those of which Athanasius gives a detailed account in his political Apologies.

But more than anything else, I would say, his original doctrine of divinization helps to reach a correct understanding of Athanasius' attitude towards Sacred Scripture. He was not exercising his intellectual leadership in the in-

18 Cfr. Contra Arianos oratio III 20-25. 
trospective and metaphysical capacity of a philosopher nor did he ever engage into a scientific exegesis of Scripture like many of his learned predecessors, or like his younger contemporary Didymus the Blind, appointed by himself as a professional exegete in Alexandria. The Athanasian interpretation of Sacred Scripture is not a scholarly enterprise. It is through and through an account of the existential battle for truth on the individual level of experience and on the collective level of the believing church-community. Interpreting Scripture means for Athanasius recounting the practical experience of life and death as a believer. More precisely accounting for life and death in a Christian perspective becomes only relevant when Scripture itself speaks about it. Such a biblical exegesis fits with Athanasis' doctrine of divinization. For it witnesses what happens to individual persons and to society at large when and where for good or bad the divine Logos, consubstantial with the Father, imposes the decisive challenges of His divinizing presence. 